\title{
8. SEISMIC EVIDENCE FOR CARBONATE BUILDUPS AT THE NORTHERN EDGE OF THE MAURICE EWING BANK, FALKLAND PLATEAU ${ }^{1}$
}

\author{
William J. Ludwig, ${ }^{2}$ Lamont-Doherty Geological Observatory of Columbia University, Palisades, New York
}

\begin{abstract}
A prominent topographic buildup is observed on one seismic reflection profile of the northern margin of Maurice Ewing Bank near $50^{\circ} \mathrm{S}$ latitude. It consists of a wedgelike body of sediments on a declined basement surface. On the basis of reflection characteristics, I suggest that it is a succession of carbonate buildups and associated deposits on a subsided shelf edge.
\end{abstract}

\section{INTRODUCTION}

The criteria for the recognition of carbonate buildups from seismic reflection data are neatly described with examples by Bubb and Hatlelid (1977) following the seismic stratigraphy terminology of Vail et al. (1977). Criteria for direct recognition of buildups include reflection configuration and onlap of reflectors against the buildup and the pattern of change in seismic facies between the buildup and adjacent strata. Indirect criteria indicating that a buildup is present include drape of strata over the buildup, spurious reflections from the edges of the buildup, and anomalies in reflection time that result from differences in velocity between the buildup and adjacent strata.

\section{MAURICE EWING BANK}

Drilling at DSDP Sites 327 and 330 and at Site 511 (this volume) on the Maurice Ewing Bank recovered Lower Cretaceous and Upper Jurassic black shales, which were deposited in an inner to outer neritic bottom environment, sometimes under anoxic conditions. Their present position at 3100 meters depth below sea level indicates that the bank has subsided by about that amount.

A multichannel seismic reflection profile of the northern margin of Maurice Ewing Bank (Fig. 1) reveals a wedge of sediment on a steeply declined basement surface (Fig. 2). From all indications, the wedge is a succession of carbonate buildups and associated deposits. Some of the criteria for recognition of the buildups and the inferred geomorphological paleoenvironments are indicated on the record section. The main criteria are (1) the change in pattern of the seismic facies downdip, from a continuous, parallel reflection configuration (back reef) to a discontinuous reflection configuration (reef facies) to a continuous, parallel reflection config-

\footnotetext{
${ }^{1}$ Ludwig, W. J., Krasheninnikov, v. A., Init. Repts. DSDP, 71: Washington (U.S Govt, Printing Office).

2 Present address: Gulf Oil Exploration and Production Company, P.O. Box 36506 , Houston, Texas 77236.
}

uration (fore reef); (2) the mounded configuration of the buildup; (3) diffractions from the front of the buildup; (4) onlap of sediments onto the buildup, and (5) sediment drape over the buildup. A prominent lens of convergent reflection cycles (lagoonal facies?) constitutes part of the back reef sequence of the sediment.

Tracing of dated reflectors from the drill sites to the northern margin of the Maurice Ewing Bank indicates that the carbonate buildups are either Upper Jurassic or Lower Cretaceous. The uncertainty stems from uncertainties in tracing reflections as continuous events over a long distance. In all likelihood, the buildups are Lower Cretaceous, formed after the breakup of Gondwanaland as a succession of reefs on a subsiding, differentiated shelf edge. A subsequent cover of Upper Cretaceous and younger sediments has been removed through erosion by bottom currents.

It should be noted that the seismic criteria that are described are characteristic, not diagnostic, of carbonate buildups. Thus we may be viewing slump masses or current-controlled deposits, which may have similar characteristics. The observation most favoring carbonate buildup is the seismic facies pattern converging away from a mounded structure, indicating a facies formed contemporaneously with the structure. The mounded structures appear not to have appreciable velocity contrast with adjacent strata; however, the interval velocity of a carbonate buildup is dependent on a number of factors, including porosity and burial history.

\section{ACKNOWLEDGMENTS}

Acquisition and processing of seismic data used in this report were supported by grant OCE77-25992 from the Oceanography Section of the National Science Foundation, U.S.A.

\section{REFERENCES}

Bubb, J. N., and Hatlelid, W. G., 1977. Seismic stratigraphy and global changes of sea level. Paŕt 10: Seismic recognition of carbonate buildups. Seismic Stratigraphy: Applications to Hydrocarbon Exploration. Am. Assoc. Pet. Geol. Mem., 26:185-204.

Vail, P. R., et al., 1977. Seismic stratigraphy and global changes of sea level. Parts 1-11. Seismic Stratigraphy: Applications to Hydrocarbon Exploration. Am. Assoc. Pet, Geol. Mem., 26:49-212. 


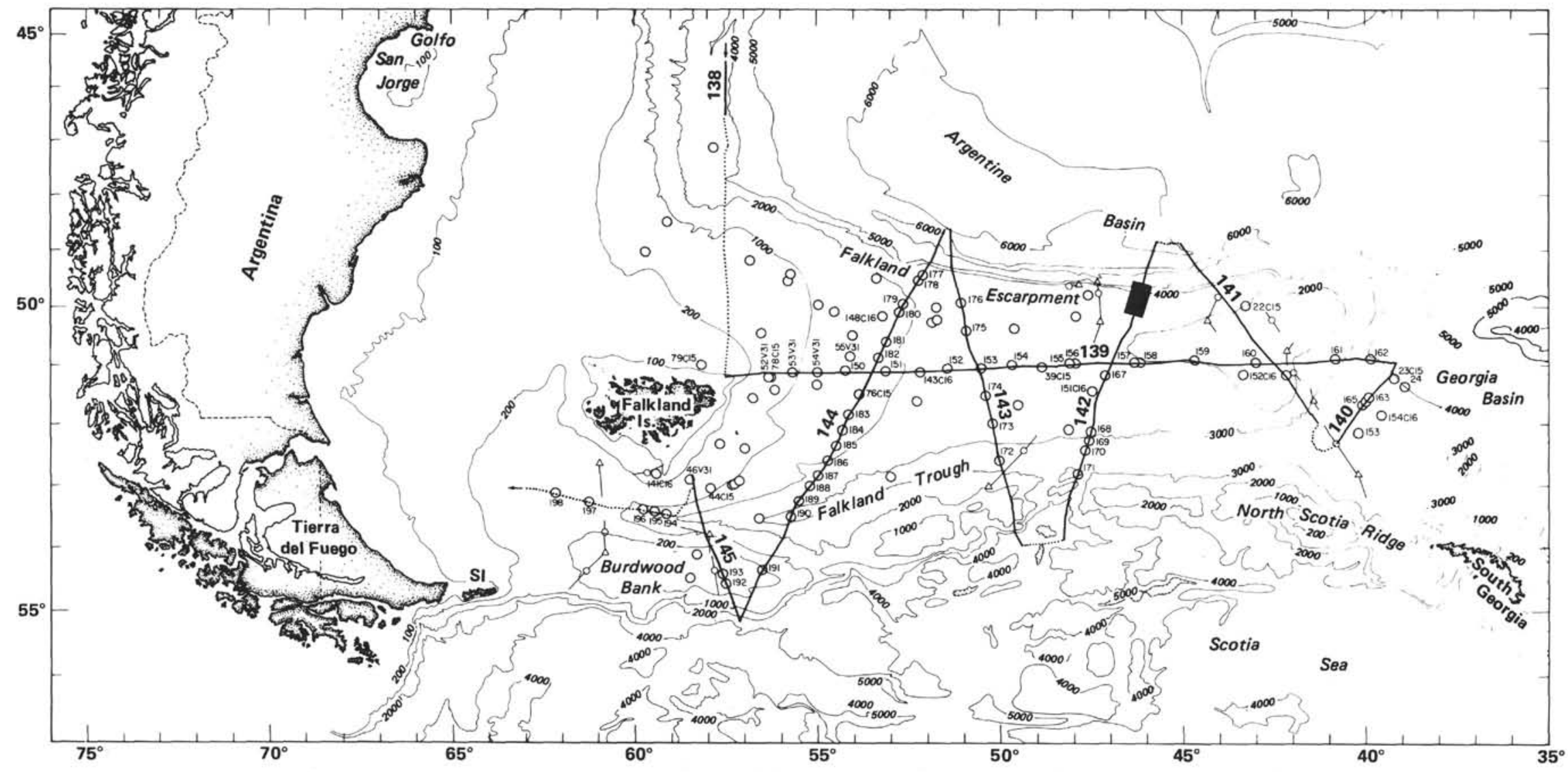

Figure 1. Location of L-DGO multichannel seismic reflection lines on the Falkland Plateau. Maurice Ewing Bank is outlined approximately by the 2000-meter isobath at the eastern end of the plateau. Circles and triangles represent locations of reflection-refraction stations. DSDP drilling sites are located near the intersection of lines 139 and 142 . Box denotes location of seismic record section in the text. 


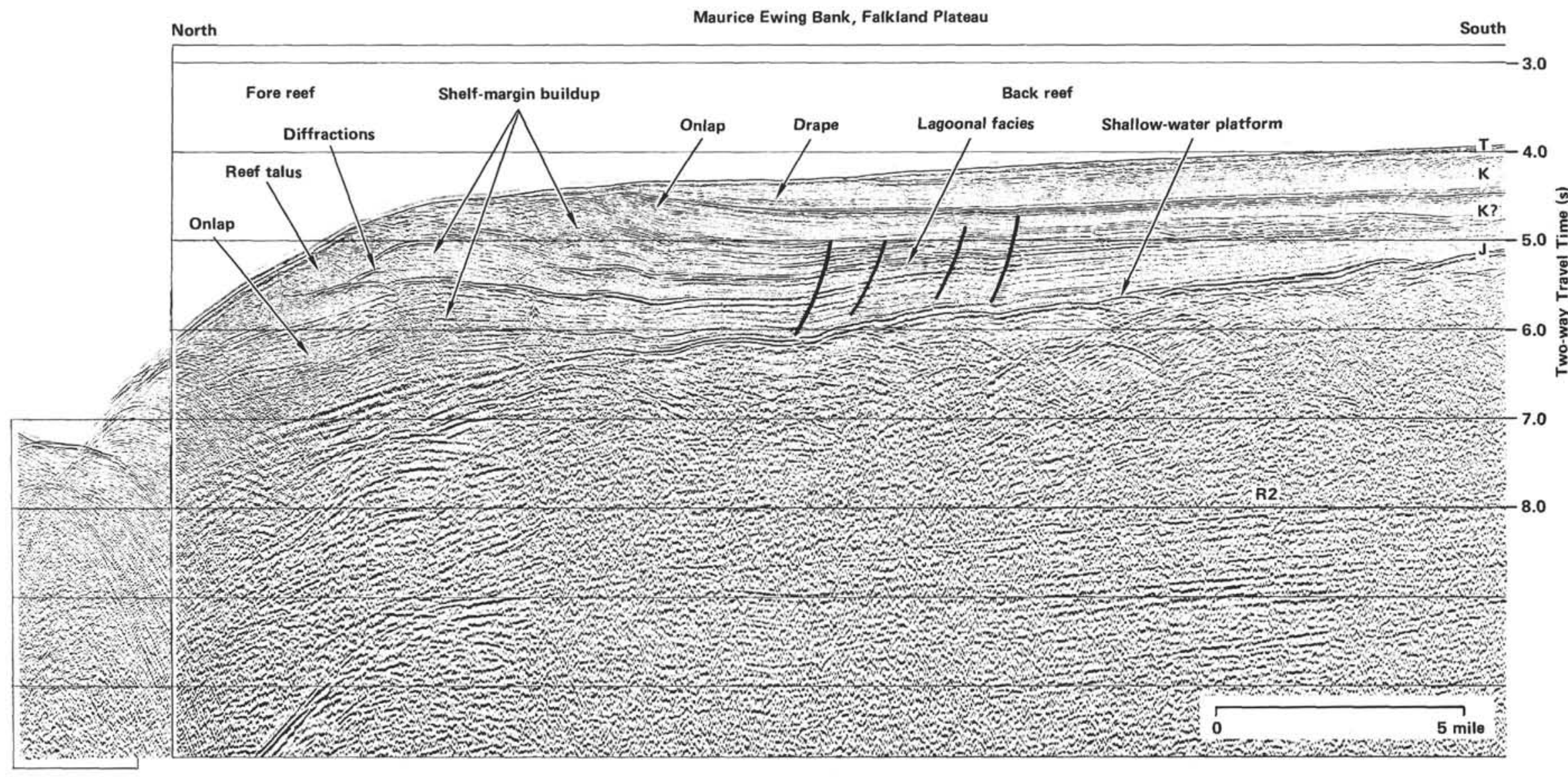

Figure 2. A 24-channel CDP stacked record section of the northern margin of Maurice Ewing Bank along MCS line 142 (L-DGO data). Location shown in Figure 1. The seismic configuration pattern is suggestive of a succession of carbonate buildups on a subsided shelf edge. (T, Tertiary; $K$, Cretaceous; $J$, Jurassic; $R_{2}$, multiple reflection from the seafloor.) 